Please note! This is a self-archived version of the original article.

Huom! Tämä on rinnakkaistallenne.

To cite this Article / Käytä viittauksessa alkuperäistä lähdettä:

Malila, R., Lehtoranta, S. \& Viskari, E.-L. (2019) The role of source separation in nutrient recovery - comparison of alternative wastewater treatment systems. Journal of Cleaner Production, 2019:219, s. 350 - 358.

DOI: https://doi.org/10.1016/j.jclepro.2019.02.024 


\title{
The role of source separation in nutrient recovery - comparison of alternative wastewater treatment systems
}

\author{
Malila, R. ${ }^{1}$, Lehtoranta, S. ${ }^{1}$, Viskari, E.-L. ${ }^{2}$ \\ 1) Finnish Environment Institute SYKE, PL 140, 00251 Helsinki, Finland, \\ riikka.malila@ymparisto.fi, suvi.lehtoranta@ymparisto.fi \\ 2) Tampere University of Applied Sciences TAMK, Kuntokatu 3, 33520 Tampere, Finland, \\ eeva.liisa.viskari@tamk.fi
}

Keywords: urine; LCA; source separation; fertilizer; nutrient recovery; wastewater treatment

\begin{abstract}
The availability of mineral fertilizers is becoming more challenging in the future. In source separated human urine, nutrient ratio is suitable for fertilizer use and nutrients are readily available for plants. In this study the aim was to acquire scientific data of the environmental impacts and nutrient potentials of wastewater separating systems, i.e. urine and blackwater source separation. At the same time, general acceptance on the use of human urine in agriculture wanted to be improved. In addition, the value of urine as a fertilizer was calculated. The focus of the study was on rural areas but comparison between different systems included also the nutrient potential of urban areas as well. Based on the results, human urine was found to be an environment friendly fertilizer. Applying source-separation systems in rural areas, four times more phosphorus and over thirty times more nitrogen could be recovered compared to the current wastewater treatment system. Furthermore, eutrophication impact is reduced to one fifth. However there is a risk of increased soil acidification but it can be minimized with advanced spreading techniques, like deep injection. The results of this study support the use of source-separation technologies for nutrient recovery.
\end{abstract}

\section{Introduction}

Recycling of nutrients is recognized as one of the key elements of the circular economy. This has been identified in several programs and targets nationally and internationally (Aho et al., 2015; EUR-Lex, 2015; Pantsar et al., 2016). Recent scientific discussion has brought up the question of the diminishing global phosphorus reserves and thus the urgent need to seek for alternative sources of phosphorus fertilization. Phosphorus is in many countries the limiting factor in food production. The availability of affordable mineral fertilizers is becoming more challenging and the prices are expected to rise (Cordell et al., 2011). It has been estimated, that there is relatively easily extractable phosphate rock reserves left for about 50-100 years (Cordell et al., 2009). Additionally, nitrogen fertilizer production is highly energy intensive. Therefore, we are soon facing a situation where more intensive nutrient reuse will be essential for producing food for the growing population. Thus, it is of utmost importance to seek means to reuse all human and animal excreta in food production in a safe and sustainable manner.

Source separated human urine and feces are nutrient-rich biomasses and could be utilized more efficiently as fertilizers. Especially in urine, nutrients are in the right amounts and readily available for plants and thus to be used in crop cultivation (Udert et al., 2006). Use of source separated human urine offers an option to meet the demand of nitrogen fertilization. Urine can be diverted from solid excreta to be used as a liquid fertilizer. This diversion enables safe reuse of waste for agriculture purposes and at the same time protects the natural water bodies from waste pollution and eutrophication (Vinnerås et al., 2002). Secondly, the use of such systems can be a valuable option next to the current available sanitation to improve the state of sanitation and lower water consumption. Closing the nutrient cycle by using urine as a natural fertilizer can furthermore boost crop production.

In Finland $85 \%$ of the population is connected to sewer networks and wastewater is treated in centralized wastewater treatment plants (WWTP) (Säylä, 2015). In rural areas, wastewater is typically collected in septic tanks or holding tanks and the sludge is transported to WWTPs for treatment. Currently, in the cities, 
there is a considerable debt in the renovation of the sewer networks and WWTPs (FCG, 2008). Also for that reason, time could be right for the reassessment of the existing wastewater treatment concepts so that nutrient recovery would be better taken into account.

In many European countries, including Finland, urine is not recognized as a fertilizer and a weak legal and institutional framework makes it difficult to implement source-separating technologies, as there is no market for the end products (EUR-Lex, 2008; Richert Stintzing et al., 2007). However, there are also European countries with a more positive attitude towards the fertilizer use of human urine, like Sweden and Denmark (Spångberg, 2014; Kvarnström, 2006). Unfortunately, urine is often paralleled with municipal sludge, even if their properties and process of formation are quite different. Many multi-national companies have recently banned the use of municipal sludge as a fertilizer in the fields from which they buy grain (e.g. Fazer, Viking Malt). In some countries, like Germany, most of the municipal sludge is incinerated, as a result of which, much of the valuable nutrients are lost (Wiechmann et al., 2015).

The public opinion towards the use of human urine and feces in crop cultivation is controversial with regard to hygiene and potential harmful substances, like pharmaceuticals and hormones. On average, two thirds of the drugs used by humans are excreted via urine and rest via feces (Lienert et al., 2007). The potential health risks associated with the use of urine and feces as fertilizers have been extensively studied, and WHO guidelines have been developed for their treatment and use (WHO, 2006). However, there is still limited information about the effects of harmful substances on human health and soil biota as well as their accumulation in the ecosystem.

Alternative technologies for nutrient recovery, such as dry toilets, separating and vacuum toilets, would enable source separation of urine and blackwater (i.e. urine and feces). These technologies could be quite easily implemented in rural and new residential areas. However, many factors are hindering the nutrient recovery on a larger scale. In addition to negative attitude related to use of human urine and feces in crop cultivation, the logistical chain, including storage, transport and spreading, and legislative barriers require solutions as well (Lienert et al., 2010; Magid et al., 2006). In Finland and in many other developed countries, only a small part of the human-excreted nutrients are exploited in agriculture. Nowadays, nutrient-rich fractions, urine and feces, are diluted with other wastewaters, and at the same time the recoverability becomes more difficult.

To recycle nutrients more efficiently, alternative wastewater treatment scenarios were studied in more detail in this paper. The use of source-separated human urine as a fertilizer was evaluated for the first time in Finland. Blackwater separation systems were included in the comparison as well, since the technology and logistics applied are simpler. In addition to theoretical calculations, including life cycle assessment (LCA) and nutrient potential evaluation, presented in this paper, field demonstrations and fertilizer tests were made in the two farms in Southern Finland (Viskari et al., 2018). In this part of the study, amounts of pharmaceuticals and hormones in the urine used as fertilizer were analyzed (total of 55 pharmaceuticals) as well as their presence in grains and soil after the growing season.

\section{Method}

\subsection{Alternative scenarios}

Two alternative source separation systems were analyzed and compared to the current wastewater treatment system (Fig. 1). The focus was on rural areas but comparison included also urban areas with regard to nutrient potential. As the cities and urban areas are largely connected to sewerages, switching to alternative options with nutrient recovery requires more extensive redevelopment and investment than in rural areas.

\subsubsection{Reference system}


The reference system of rural areas (Fig. 1, A0/R) was defined as a system in which all wastewater (urine, feces, greywater) from the property was assumed to be treated on-site in a three-chamber septic tank and in a following sand filter. Excessive sludge from the septic tank was assumed to be transported to a WWTP 1.5 times a year.

\subsubsection{Urine separation system}

In the urine separation system (Fig. 1, A1), urine, and feces were assumed to be collected separately with a separating dry toilet. $95 \%$ of the urine was assumed to be recovered, yet the rest ended up with feces.

Collected urine was assumed to be stored at the property and transported once a year to a field to be used as a fertilizer. Feces were assumed to be composted in a composter and the compost used at the property. Greywater was treated similarly as in the reference system, except that the septic tank sludge was assumed to be transported to the WWTP once a year.

\subsubsection{Blackwater separation system}

In the blackwater separation system (Fig. 1, A2), urine and feces were assumed to be collected together in a vacuum toilet system. The mixture of urine, feces, and flush water (together blackwater) was assumed to be transported to an anaerobic digestion plant once a year. The digestate was assumed to be used for fertilizer purposes and greywater treated similarly as in the urine separation system. 


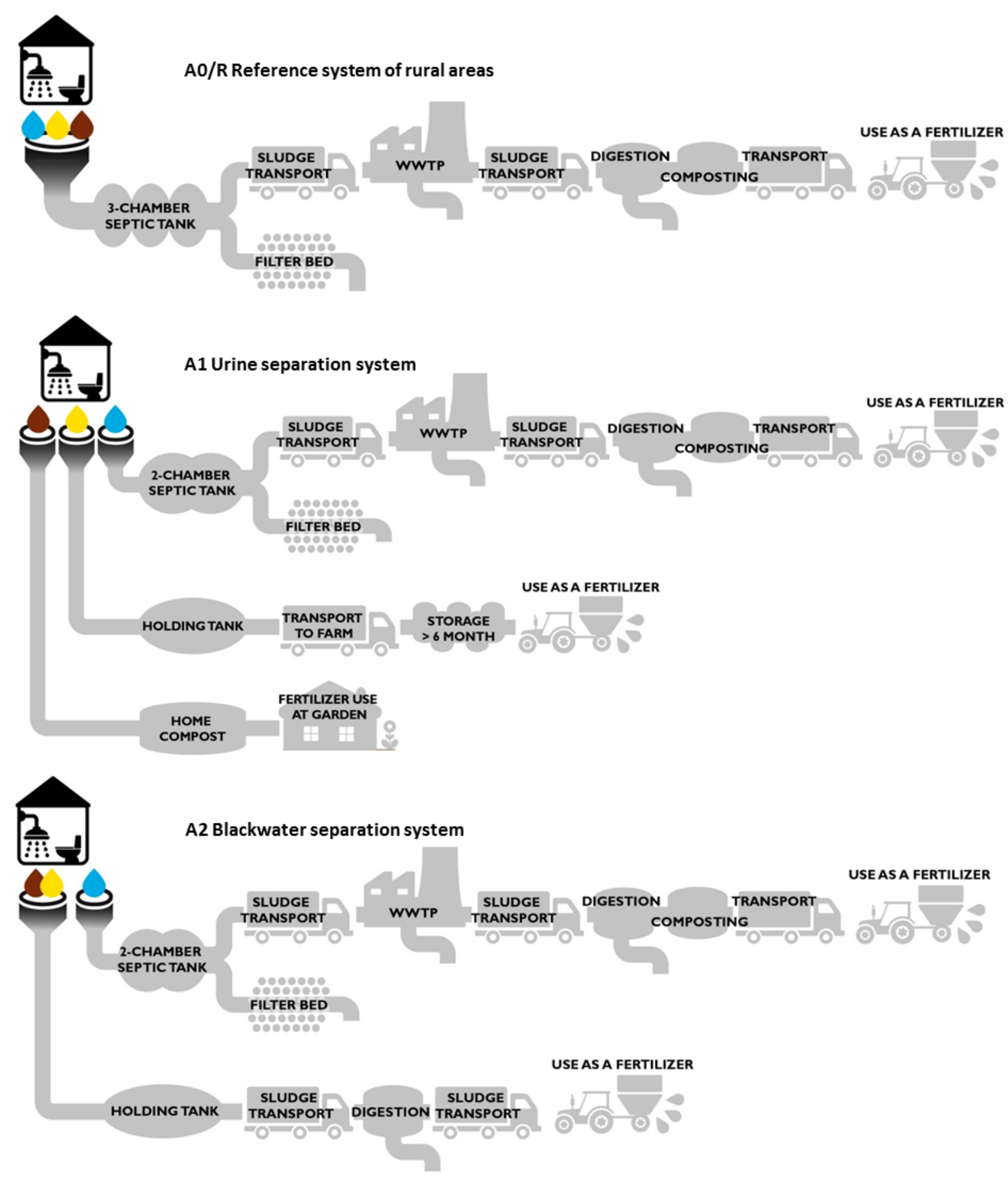

Fig. 1. Alternatives for nutrient recycling in rural areas compared to present situation (reference system): AO/R Reference system of rural areas: Wastewater is treated on-site and sludge from the septic tank is treated in a WWTP.

A1 Urine separation system: Urine and feces are collected separately with a separating dry toilet, urine is transported and used as a fertilizer, feces is composted on-site, greywater treated similarly as in the AO/R. A2 Blackwater separation system: Urine and feces are collected together with a vacuum toilet system and transported and treated for fertilizer purposes, greywater is treated similarly as in AO/R.

\subsection{Common assumptions}

A basic assumption of the amount of nutrients produced by one person per year is given in Table 1 . 
Table 1. The amount of nutrients produced by one person per year (Ministry of the Environment Finland 157/2017; Udert et al., 2006; Weckman, 2005).

\begin{tabular}{|c|c|c|c|}
\hline Fraction & $\begin{array}{l}\mathrm{N} \\
\text { (kg/a/person) }\end{array}$ & $\begin{array}{l}\mathbf{P} \\
\text { (kg/a/person) }\end{array}$ & $\begin{array}{l}\mathrm{BOD}_{7} \\
\text { (kg/a/person) }\end{array}$ \\
\hline Urine & 4,13 & 0,40 & 1,83 \\
\hline Feces & 0,52 & 0,21 & 5,48 \\
\hline Other & 0,37 & 0,15 & 10,95 \\
\hline Total & 5,02 & 0,75 & 18,25 \\
\hline
\end{tabular}

\subsubsection{WWTP}

In every scenario the WWTP was assumed to consist of the following steps commonly used in the Finnish WWTPs; pretreatment, i.e. grit removal and screening, primary sedimentation, activated sludge process with simultaneous precipitation and drying of the sludge. Further processing of the sludge, i.e. digestion and composting, was assumed to be carried out in a separate facility. The composted sludge produced as the end product was assumed to be used almost entirely in landscaping $(97 \%)$ and the rest in agriculture (3\%) corresponding to the current practice in Finland (Eurostat, 2016).

The average treatment efficiencies of the five Finnish medium-sized WWTPs were used in the calculations (VAHTI, 2015), and were $98 \%$ for organic matter, $64 \%$ for nitrogen and $96 \%$ for phosphorus, respectively. The treatment efficiency of primary sedimentation was assumed to be $30 \%$ for organic matter and $10 \%$ for nitrogen. It was also assumed that roughly half of the organic matter left after primary sedimentation is bound to the biomass in activated sludge process, and roughly the same amount is evaporated as a carbon dioxide as a result of microbial metabolism. Using the nutrient ratio (C:N:P) of 100:5:1 in activated sludge phase, the amounts of nitrogen and phosphorus bound to bio-sludge were $21 \%$ and $11 \%$, respectively. As a result, the emission factor for $\mathrm{N}_{2}$ was $0.07 \mathrm{~kg} \mathrm{~N}_{2} / \mathrm{kg} \mathrm{N}_{\text {influent. }}$

Air emissions of the WWTP, as well as energy consumption were calculated according to the emission factors given in Table 2 . Of the chemicals, ferrous sulphate and lime were considered, with consumption values of $0.18 \mathrm{~kg} \mathrm{FeSO}_{4} / \mathrm{kg} \mathrm{P}_{\text {influent }}$ and $0.064 \mathrm{~kg} \mathrm{CaO} / \mathrm{kg} P_{\text {influent, }}$ respectively. For the excessive sludge, the value of $1.53 \mathrm{~kg}$ sludge $/ \mathrm{m}^{3}$ influent was used. Average dry solids content of the sludge was $20.6 \%$. (HSY 2014, 2015, 2016)

Table 2. Coefficients and emission factors used in the calculations.

\begin{tabular}{|c|c|c|}
\hline Characteristic & Emission factor & Reference \\
\hline \multicolumn{3}{|l|}{ WWTP } \\
\hline Energy consumption & $\begin{array}{l}0,48 \mathrm{kWh} / \mathrm{m}_{31 \mathrm{~N}} \\
\text { (electricity } 0,36 / \text { heat } 0,12 \mathrm{kWh} / \mathrm{m}_{3}\end{array}$ & $\begin{array}{l}\text { Myllymaa et al., 2008; Pöyry, 2007; Tampere Water, 2012, 2013; } \\
\text { Tukiainen, } 2011\end{array}$ \\
\hline Methane, $\mathrm{CH}_{4}$ & $0,002 \mathrm{~kg} \mathrm{CH}_{4} / \mathrm{kg} \mathrm{BOD}$ IN & $\begin{array}{l}\text { Daelman et al., } 2012 \text { \& 2013, HSY 2014, 2015, 2016; Wang et al, } \\
2011\end{array}$ \\
\hline Nitrous oxide, $\mathrm{N}_{2} \mathrm{O}$ & $0,022 \mathrm{~kg} \mathrm{~N}_{2} / \mathrm{kg} \mathrm{N} \mathrm{N}_{\mathrm{N}}$ & $\begin{array}{l}\text { Foley et al., 2010, 2011; HSY, 2014, 2015, 2016; Kampschreur, } \\
\text { 2009; Kosonen et al., 2016; Wicht and Beier, } 1995\end{array}$ \\
\hline Ammonia, $\mathrm{NH}_{3}$ & $0,00015 \mathrm{~kg} \mathrm{NH}_{3} / \mathrm{kg} \mathrm{N}_{\mathrm{IN}}$ & HSY 2014, 2015, 2016 \\
\hline Nitrogen oxide, $\mathrm{NO}_{x}$ & $0,00062 \mathrm{~kg} \mathrm{NO}_{x} / \mathrm{kg} \mathrm{N} \mathrm{N}_{\mathrm{N}}$ & HSY 2014, 2015, 2016 \\
\hline \multicolumn{3}{|l|}{ Anaerobic digestion } \\
\hline Energy consumption/production & $\begin{array}{l}\text { consumption } 0,22 \mathrm{kWh} / \mathrm{m}_{3} \mid \mathrm{N} \\
\text { (electricity } 0,04 / \text { heat } 0,18 \mathrm{kWh} / \mathrm{m}_{3} \\
\text { production } 0,46 \mathrm{kWh} / \mathrm{m}_{3 \mid \mathrm{N}} \\
\text { (electricity } 0,16 / \text { heat } 0,3 \mathrm{kWh} / \mathrm{m}_{3}\end{array}$ & $\begin{array}{l}\text { Myllymaa et al., 2008; Pöyry, 2007; Tampere Water, 2012, 2013; } \\
\text { Tukiainen, } 2011\end{array}$ \\
\hline Methane, $\mathrm{CH}_{4}$ & $0,006 \mathrm{~kg} \mathrm{CH}_{4} / \mathrm{kg} \mathrm{BOD}$ IN & $\begin{array}{l}\text { Daelman et al., 2012, 2013; HSY 2014, 2015, 2016; Wang et al., } \\
2011\end{array}$ \\
\hline Carbon dioxide, $\mathrm{CO}_{2}$ fossil & $0,012 \mathrm{~kg} \mathrm{CO}_{2}$ fossil $/ \mathrm{kg} \mathrm{BOD}$ IN & HSY 2014, 2015, 2016 \\
\hline \multicolumn{3}{|l|}{ Composting } \\
\hline Energy consumption & $20 \mathrm{kWh} / \mathrm{tin}(\mathrm{dry}$ cont. $30 \%)$ & Myllymaa et al., 2008; Pöyry, 20017, Tukiainen, 2011 \\
\hline Methane, $\mathrm{CH}_{4}$ & $0,02 \mathrm{~kg} \mathrm{CH}_{4} / \mathrm{kg} \mathrm{BOD}$ IN & $\begin{array}{l}\text { Andersen et al., 2010, 2012; Brown et al., 2007; Osada et al., 2000; } \\
\text { Washington State University, } 2016\end{array}$ \\
\hline
\end{tabular}




\subsubsection{On-site wastewater treatment}

In every scenario a reference system of on-site wastewater treatment was assumed to be a septic tank and a sand filter. The sand filter is constructed as a wide excavation filled with suitable sand and gravel layers and wastewater infiltrates through the filter bed and is collected into the pipes in the bottom and led to a discharge. In the reference system of rural areas (AO/R) both blackwater and greywater produced at the property were assumed to be treated in the sand filter, while in the alternative scenarios ( $A 1 \& A 2)$, only greywater.

The treatment efficiencies of the sand filter were assumed to be $90 \%$ for BOD, $70 \%$ for total phosphorus and $30 \%$ for nitrogen, which are the minimum requirements according to the Finnish legislation (Ministry of the Environment Finland 157/2017). The treatment efficiencies of the septic tank were assumed to be 27 $\%$ for BOD, $23 \%$ for total phosphorus and $9 \%$ for nitrogen, indicating that $80 \%$ of the nutrients in feces and $5 \%$ in greywater were removed in the septic tank (Ministry of the Environment Finland, 2017).

In Finland, the weather conditions fluctuate in the course of the year (e.g. soil frosting, snowpack and melt). Emissions to water are, therefore, difficult to measure. The eutrophication emission factor (Lehtoranta et al., 2014) was used to describe the amount of nutrients ending up to freshwater ecosystem after initial emission from the sand filter to the soil. The eutrophication emission factor of the sand filter was set to 0.5 indicating that $50 \%$ of the nutrients were assumed to be leached.

In the case of air emissions of the on-site wastewater treatment only methane $\left(\mathrm{CH}_{4}\right)$ and nitrous oxide $\left(\mathrm{N}^{2} \mathrm{O}\right)$ were taken into account, while ammonia $\left(\mathrm{NH}_{3}\right)$ and nitrogen oxides $\left(\mathrm{NO}_{x}\right)$ were assumed to be insignificant. The same emission factors were applied as in the WWTP, except the emission factor of nitrous oxide was assumed to be a half of the one in the WWTP.

\subsubsection{Home composting}

Air emissions of home composting were calculated according to emission factors given in Table 2. It was assumed that in the home-compost, one third of litter, mixture of peat ( $5 \mathrm{~kg} /$ person/a) and wood chips ( $8 \mathrm{~kg} /$ person/a), was added in relation to feces. Kitchen waste was not included in the system boundaries. In addition to table 2, an emission factor of $860 \mathrm{~kg} \mathrm{CO}_{2} / \mathrm{t}$ peat (Manninen et al., 2016) was used for the degradation of peat over a hundred year time horizon. However, the soil emissions during the production of peat were ignored due to the uncertainties involved and the low importance of emissions (Grönroos et al., 2013). The eutrophication emissions from the home composting were considered negligible.

\subsubsection{Storage and transport of urine and blackwater}

As a result of urea hydrolysis, urine $\mathrm{pH}$ rises, which expose to ammonia loss during storage and transport phases of urine and blackwater. As the loss of ammonia cannot be totally prevented, it was assumed that 1 $\%$ of the total nitrogen of urine (A1) and blackwater (A2) evaporates as ammonia during storage at the property and subsequent transport. Any air emissions from the toilet systems were assumed to be insignificant.

\subsubsection{Further processing of sludge, urine, and blackwater}

In the scenario A1, the collected urine was assumed to be made hygienic by storing on a farm at least 6 months, after which it will be applied to field without further treatment. During the hygienization, $0.5 \%$ of 
the total nitrogen of urine was assumed to be volatilized as ammonia mainly as a result of the uncontrolled leakage (Udert et al., 2006). In the scenario A2, the collected blackwater were supposed to be digested in an anaerobic digestion plant.

The nitrous oxide released in the digestion was assumed to be insignificant. $5 \%$ of nitrogen and phosphorus were assumed to accumulate on the walls of the digestion reactor (Schievano et al., 2011). In addition, $70 \%$ of nitrogen, $40 \%$ of phosphorus, and $35 \%$ of organic matter of the sludge was assumed to end up in the reject water of the digestion (Heinonen, 2014; Wäger-Baumann, 2011). The treatment of reject water was excluded from the system.

The dry matter content of the digestate to be composted was estimated at $30 \%$. The digestate was assumed to be composted together with peat and silt in a ratio of $45 \%$ digested sludge, $36 \%$ silt and $18 \%$ of peat (Metsäpirtti Ltd). It was assumed that $55 \%$ of the carbon is evaporated as carbon dioxide during composting (Andersen et al., 2010, 2012; Brown \& Subler, 2007; Osada et al., 2000). The dry matter content of the finished compost was assumed to be $40 \%$. Emission compensation was calculated for the heat and electricity generated during the digestion.

Both the digestion and composting produces emissions both as direct evaporation emissions and through energy consumption. The energy consumption and production of the digestion and the energy consumption of composting as well as emission factors used in the calculation are given in Table 2.

\subsubsection{Fertilizer use}

Advanced spreading techniques (injection) were assumed to be used in the application of urine, digested blackwater and digested and composted sludge to the field. With these techniques ammonia volatilization can be minimized even in a level of $1-10 \%$ (Johansson, 2001; Udert et al., 2006). The value of $15 \%$ was used for ammonia volatilization and $1 \%$ for nitrous oxide (IPCC, 1996). The energy consumption of potential pumping was assumed to be negligible.

Emission compensation was calculated for the fertilizer use of urine, digested blackwater and digested and composted sludge assuming that they replace mineral fertilizers. Only the amount of soluble nitrogen was taken into account, and was assumed to be $100 \%$ for urine, $13 \%$ for digested sludge, and $8 \%$ for digested and composted sludge (Salmela et al., 2014). For phosphorus, the values were, $100 \%$ for urine and $40 \%$ for both the digested and composted sludge according to the terms of the Finnish farmer support system.

\subsubsection{Transport}

The emissions of the vehicle used were obtained from VTT's (Technical Research Centre of Finland) LIPASTO databases (2011) (Finnish traffic exhaust emissions and energy consumption calculation system). Supplies related to maintenance of the systems were not taken into account because they were assumed to be associated with other grocery shopping trips (Table 3 ).

Table 3. Transport and distances.

\begin{tabular}{lcl}
\hline Transport type & Round trip (km) & Used vehicle \\
\hline Equipment & 50 & lorry (Euro 5, diesel, 9t full load) \\
Soil & 30 & semi trailer (Euro 5 diesel, 17,5t 70\% load), full trailer combination (Euro 5 diesel, 40 t full load) \\
Raw materials to the factory & 250 & full trailer combination (Euro 5 diesel, 40 t full load) \\
Septic tank sludge & 50 & lorry (Euro 5, diesel, 9t full load) \\
Urine to hygienization & 50 & lorry (Euro 5, diesel, 9t full load) \\
Sludge to digestion & 50 & full trailer combination (Euro 5 diesel, 40 full load) \\
Blackwater to digestion & 20 & lorry (Euro 5, diesel, 9t full load) \\
Digestate to composting & 100 & full trailer combination (Euro 5 diesel, 40t full load) \\
Compost to application & full trailer combination (Euro 5 diesel, 40t full load) \\
\hline
\end{tabular}




\subsection{Nutrient potential}

Mass balance calculation was used to determine the nutrient potential per capita per year ( $\mathrm{g} \mathrm{N}$ and $\mathrm{P} / \mathrm{a}$ /person). Also, the value of urine as a fertilizer was estimated by calculating the prices of nutrients of mineral fertilizers and soil conditioners, as a reference. In addition rough estimations of the annual costs, including investments, use and maintenance, of source separation systems compared to the reference system were made. The nutrient potential of the current wastewater treatment system used in rural (AO/R) and urban areas $(\mathrm{AO} / \mathrm{U}$ ) were compared to the alternative scenarios ( $\mathrm{A} 1$ and $\mathrm{A} 2$ ). The current wastewater treatment system in urban areas is described in 2.2.1. Mass balance calculations were made for nitrogen and phosphorus.

\subsection{Life cycle assessment (LCA)}

Environmental impacts of alternative systems (Fig. 1) were analyzed by using comparative life cycle assessment (LCA) (ISO 14040, 2006; ISO 14044, 2006). The impact categories chosen were climate change, freshwater eutrophication and acidification. The amount of nutrients produced by one person per year was chosen as a functional unit (Table 1). For impacts on freshwater eutrophication Finland-specific characterization factors (for $\mathrm{P}, \mathrm{N}$ and $\mathrm{NH}_{3}$ ) were used (Seppälä et al., 2004). For climate change and acidification ReCiPe Midpoint $\mathrm{H}$ method was used and completed with the updated global warming potential characterization factors for $\mathrm{CH}_{4}$ and $\mathrm{N}_{2} \mathrm{O}$ (IPCC, 2014). Normalization was made by using European level normalization factors (ReCiPe Midpoint $\mathrm{H}$ method) where the impacts are compared to the European average annual emissions of the consumption. No weighting was used.

Calculations and wastewater treatment scaling were made for a household of three persons with $85 \%$ annual use. The total time span for examination was 20 years. In addition, a complete renovation of an old sanitation system was assumed at the property, e.g. new toilet facilities, sand filter, sewer pipes etc. The basic assumptions regarding the alternative scenarios are presented in Table 4.

Table 4. The basic assumptions regarding the equipment in the alternative systems (Building information, 2013; Manufacturers).

\begin{tabular}{|c|c|c|c|}
\hline & $\begin{array}{l}\text { A0/R Reference system of } \\
\text { rural areas }\end{array}$ & A1 Urine separation system & $\begin{array}{l}\text { A2 Blackwater separation } \\
\text { system }\end{array}$ \\
\hline Toilet system & water toilet (20 years) & separating dry toilet (15 years) & vacuum toilet system (20 \\
\hline Materials & $28 \mathrm{~kg}$ porcelain & $\begin{array}{c}29 \mathrm{~kg} \mathrm{PE}, 2,5 \mathrm{~kg} \text { steel, } 5 \mathrm{~kg} \\
\text { fibreglass }\end{array}$ & $28 \mathrm{~kg}$ porcelain \\
\hline Electrical equipment & & fan, $10 \mathrm{~W}$ (0,5 kg PE / 8 years) & $\begin{array}{l}\text { vacuum pump, } 900 \mathrm{~W} \text { (10kg } \\
\text { bronze, } 8 \mathrm{~kg} \text { steel / } 8 \text { years) }\end{array}$ \\
\hline Pipes, life span & $\begin{array}{c}16 \mathrm{~m}(\mathrm{PP}, \varnothing 110 \mathrm{~mm} / 15 \\
\text { years })\end{array}$ & $\begin{array}{c}16 \mathrm{~m}(\mathrm{PP}, \varnothing 110 \mathrm{~mm} / 15 \\
\text { years })\end{array}$ & $\begin{array}{c}24 \mathrm{~m} \text { (PP/PE } \varnothing 50 \mathrm{~mm} / 15 \\
\text { years) }\end{array}$ \\
\hline Holding Tank & & $\begin{array}{l}150 \mathrm{~kg} \mathrm{PE}, 2 \mathrm{~m}^{3}, 15 \text { years } \\
\text { (storage of urine) }\end{array}$ & $\begin{array}{l}265 \mathrm{~kg} \mathrm{PE}, 5,4 \mathrm{~m}^{3}, 15 \text { years } \\
\text { (storage of blackwater) }\end{array}$ \\
\hline Pipes, life span & & $\begin{array}{c}10 \mathrm{~m}(\mathrm{PE}, \varnothing 110 \mathrm{~mm} / 15 \\
\text { years })\end{array}$ & \\
\hline $\begin{array}{l}\text { Excavation for the holding tank and } \\
\text { the pipes there }\end{array}$ & & $30,5 \mathrm{~m}^{3}$ & $42 \mathrm{~m}^{3}$ \\
\hline Crushed gravel $5-16 \mathrm{~mm}\left(1,45 \mathrm{t} / \mathrm{m}^{3}\right)$ & & $12 \mathrm{~m}^{3}$ & $22 \mathrm{~m}^{3}$ \\
\hline Composter & & 30 kg PE (20 years) & \\
\hline Sand filter & black and greywater, 20 years & greywater 20 years & greywater, 20 years \\
\hline Septic tank & $150 \mathrm{~kg} \mathrm{PE}, 2 \mathrm{~m}^{3}$ & $112,5 \mathrm{~kg} \mathrm{PE}, 1,5 \mathrm{~m}^{3}$ & $112,5 \mathrm{~kg} \mathrm{PE}, 1,5 \mathrm{~m}^{3}$ \\
\hline Pipes & $105 \mathrm{~m}(\mathrm{PE}, \varnothing 110 \mathrm{~mm})$ & $92 \mathrm{~m}(\mathrm{PE}, \varnothing 110 \mathrm{~mm})$ & $92 \mathrm{~m}(\mathrm{PE}, \varnothing 110 \mathrm{~mm})$ \\
\hline Distribution and sampling wells & $2 \times 20 \mathrm{~kg} P E, 170 \mathrm{I}$ & $2 \times 20 \mathrm{~kg}$ PE, $170 \mathrm{I}$ & $2 \times 20 \mathrm{~kg} P E, 170 \mathrm{I}$ \\
\hline Excavation for the filter bed and tanks & $200 \mathrm{~m}^{3}$ & $166 \mathrm{~m}^{3}$ & $166 \mathrm{~m}^{3}$ \\
\hline $\begin{array}{l}\text { Sand 0-8 } \mathrm{mm}\left(1,55 \mathrm{t} / \mathrm{m}^{3}\right) \\
\quad \text { - filter layer }\end{array}$ & $35 \mathrm{~m}^{3} / 54 \mathrm{t}$ & $27 \mathrm{~m}^{3} / 40 \mathrm{t}$ & $27 \mathrm{~m}^{3} / 40 \mathrm{t}$ \\
\hline $\begin{array}{l}\text { Crushed gravel } 5-16 \mathrm{~mm}\left(1,45 \mathrm{t} / \mathrm{m}^{3}\right) \\
\text { - around pipes and tanks }\end{array}$ & $27 \mathrm{~m}^{3} / 39 \mathrm{t}$ & $25 \mathrm{~m}^{3} / 36 \mathrm{t}$ & $25 \mathrm{~m}^{3} / 36 \mathrm{t}$ \\
\hline
\end{tabular}


Crushed gravel 8-16 mm $\left(1,45 \mathrm{t} / \mathrm{m}^{3}\right)$

- collecting layer

Crushed gravel $16-32 \mathrm{~mm}\left(1,5 \mathrm{t} / \mathrm{m}^{3}\right)$

- distribution layer
$8,5 \mathrm{~m}^{3} / 12 \mathrm{t}$

$11 \mathrm{~m}^{3} / 16,5 \mathrm{t}$
$8,5 \mathrm{~m}^{3} / 12 \mathrm{t}$

$11 \mathrm{~m}^{3} / 16,5 \mathrm{t}$

The system boundary was similar for each case (Fig. 2). Each scenario included all related raw material extraction, transportation, production of materials and components, energy production as well as compensations from fertilizer and energy use. The disposal and recycling of products were excluded. The primary data were collected mainly from literature, and partly directly from the companies. The secondary data were obtained mainly from Ecoinvent (Swiss Centre for Life Cycle Inventories, 2007) and the LIPASTO databases (VTT, 2011). Calculations were made by using the Simapro-program.

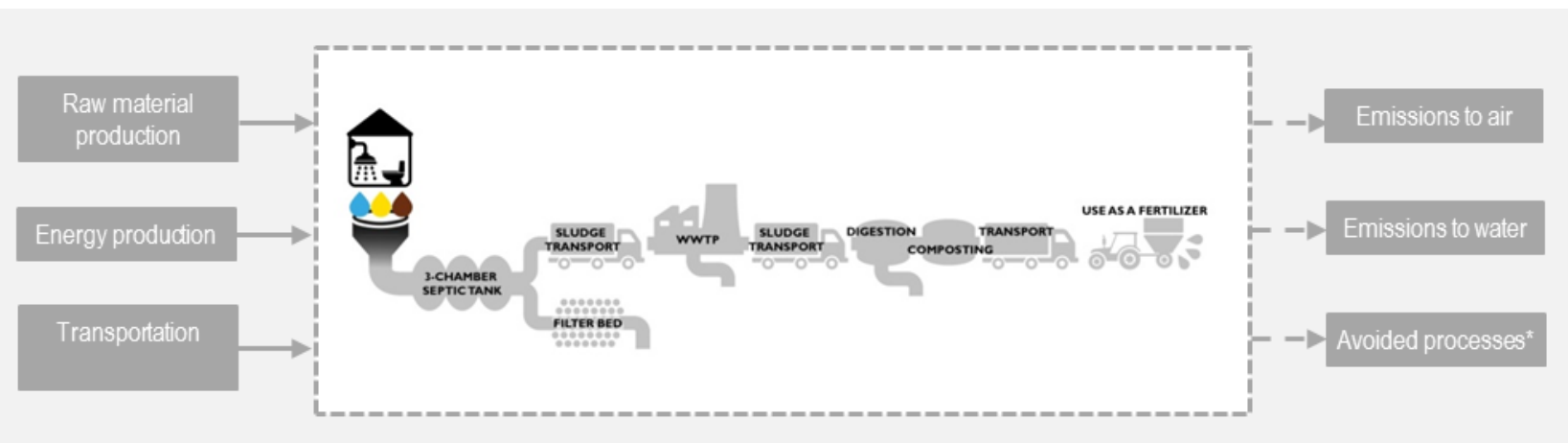

Fig. 2. Flowchart of the LCA system boundaries (example from the scenario AO). Avoided processes include fertilizer and energy production.

\section{Results and Discussion}

\subsection{Nutrient potential}

Path of nutrients in alternative scenarios is shown in Fig. 3. According to the calculations made in this study, in the reference scenario of rural areas (AO/R) two-thirds of nitrogen and one-third of phosphorus gets into the environment (water/soil) through the on-site wastewater treatment system. The amount of nutrients reaching water bodies depend primarily on the location and type of the soil. At the same time only a tiny fraction of nitrogen and one tenth of phosphorus ends up to the digested and composted sludge, after the treatment in the WWTP. The nutrient potential in rural areas is thus very small. This is mainly explained by the fact that only the surplus sludge from the septic tanks is treated in the WWTPs.
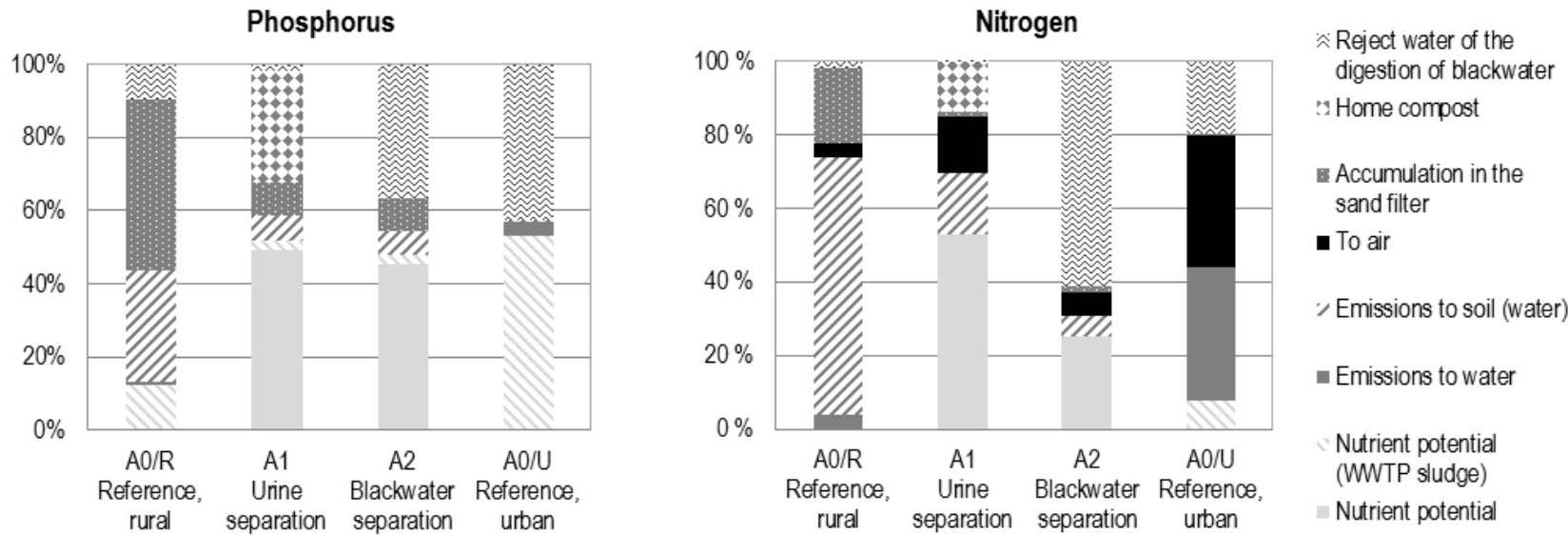

Fig. 3. Path of nutrients in alternative scenarios. 
In the cities and urban areas roughly a fair half of phosphorus and less than a tenth of nitrogen ends up to the digested and composted sludge (AO/U). The disadvantage with WWTP sludge is that phosphorus is mostly combined chemically and is therefore not easily available for plants. On average more than a third of nitrogen ends up to water bodies and a significant part of nutrients to reject water of the digestion which, in many cases, is conducted back to the beginning of the WWTPs. The results of this study indicate the huge nutrient potential of the reject waters and clearly show the need to recover the nutrients instead of re-treatment in the WWTPs.

If urine or blackwater separation systems would be applied in rural areas, over two-thirds of humanderived nitrogen and phosphorus could be recovered and used as fertilizers. At the same time as much as four times more phosphorus and over thirty times more nitrogen could be recovered compared to the reference system of rural areas (Fig. 4). Nitrogen potential is the highest in the urine separation system (A1) but almost at the same level in the blackwater separation system (A2). In the first one, nitrogen ends up mostly to urine but also to home-compost, and in the second one to blackwater and reject water of the digestion. The amount of nitrogen in the reject water of the digestion is even two times higher compared to blackwater.
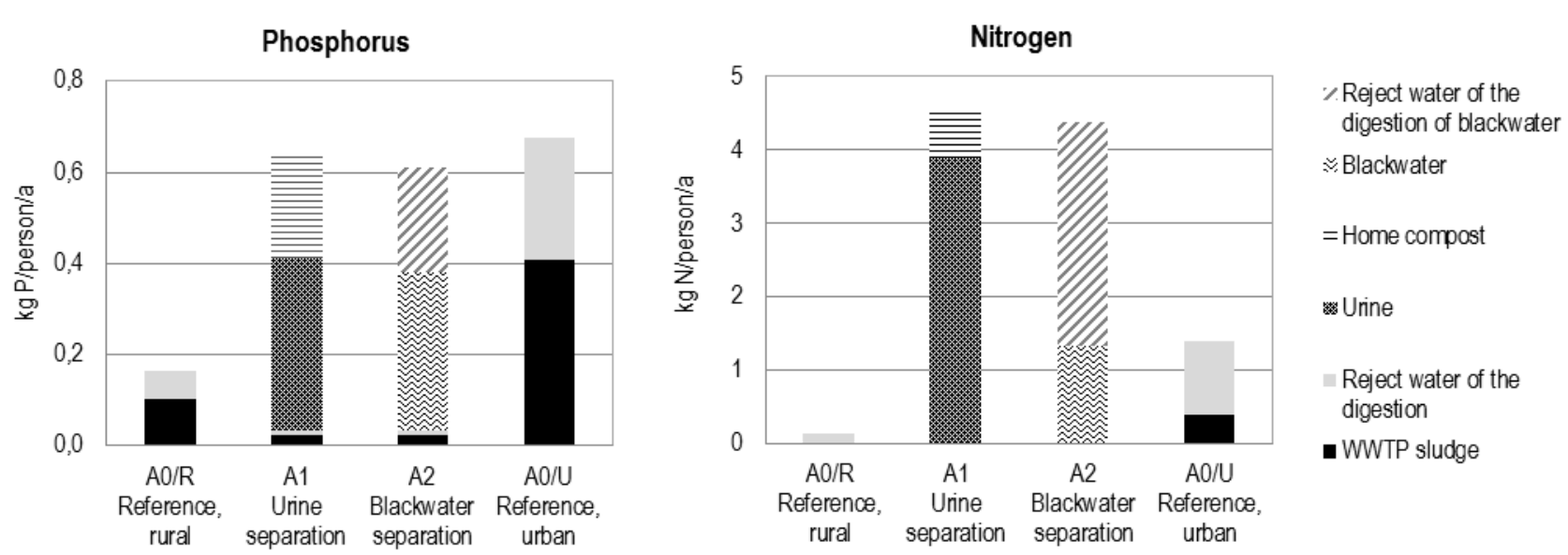

Fig. 4. Nutrient potential of the alternative scenarios compared to the present wastewater treatment systems in rural and urban areas.

For phosphorus, the nutrient potential is almost at the same level in the urine and blackwater separation systems as well as in the reference system of urban areas. However, even the phosphorus potential is quantitatively highest in the latter one the feasibility of the chemically precipitated phosphorus for the plants is not the most optimal as stated above. In the urine and blackwater separation systems urine and blackwater are the primary source of phosphorus, but significant amount is also available in home-compost and reject water of the digestion.

In Finland, the fertilizer use of phosphorus in agriculture is more than $30000 \mathrm{t} / \mathrm{a}$, of which the proportion of recycled fertilizer products is over $50 \%$ and that of nitrogen above $230000 \mathrm{t} / \mathrm{a}$, of which recycled fertilizer products account for about a third (Ministry of Agriculture and Forestry, 2011a). By utilizing source separation techniques, annually over 2000 tons of phosphorus and 14000 tons of nitrogen could be recovered, on the Finnish scale.

When comparing the nutrients content of urine to the prices of commercial fertilizers on the market, urine was found to be an economically reasonable fertilizer. The most valuable nutrients were nitrogen and potassium. The calculated nutrient value of urine was about $13 € / t(5 € /$ person/a), of which more than a third will be spent on transport and distribution costs. However, the value can be considered significant as when using urine as fertilizer, the farmer can benefit up to $70 € /$ ha depending on the nutrients needed in the soil. The annual costs, including investment and use, of the urine separation and blackwater separation systems were $29 \%$ and $89 \%$ higher compared to the reference system, respectively. This was mainly due 
to higher investment costs of the toilet systems. However, all the transportation costs, including e.g. the transportation of urine to fields and blackwater to further treatment, were negligible.

\subsection{Life cycle assessment (LCA)}

Overall, environmental impacts, normalized by the European average annual emissions of the consumption, were relatively small (Fig. 5). The climate change impact was only 0.5 to $0.6 \%$ and differences between reference system and the scenarios were low. Some variation could be seen in the eutrophication and acidification impacts. The eutrophication impact, however, was up to $15 \%$ in the reference system, but was reduced to less than a fifth in alternative systems. Acidification impacts were small, but in the urine separation system, the impact increased by a few percentage points. The biggest effect was observed in the reference system of rural areas in eutrophication due to the fact that a significant part of the nutrients ends up to water bodies through the on-site wastewater treatment system.

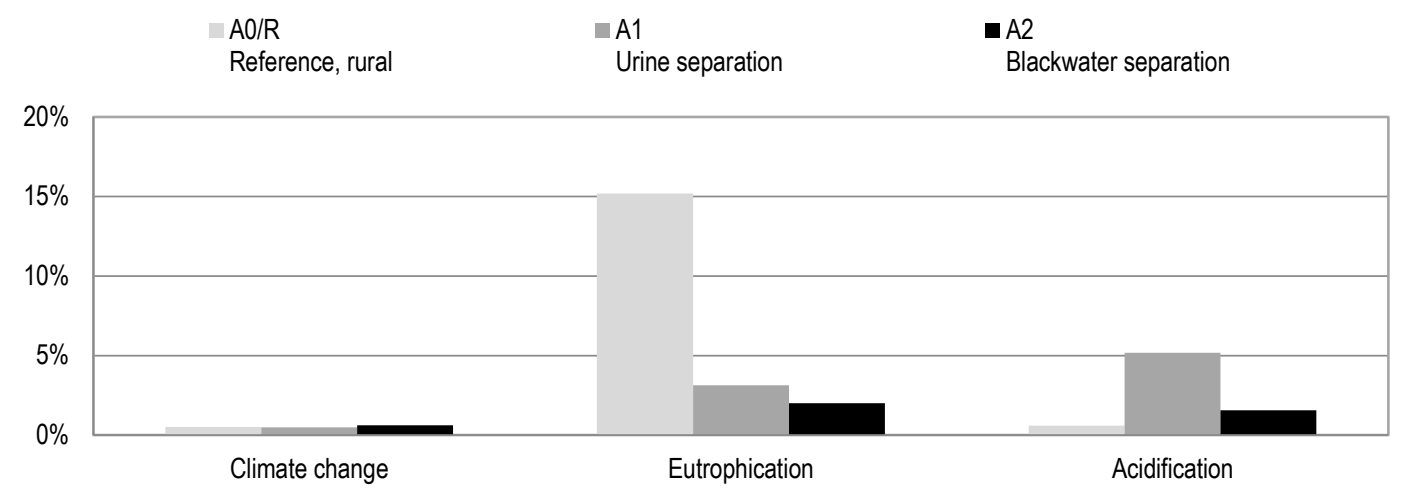

Fig. 5. Environmental impacts of the alternative scenarios normalized by the European average annual emissions of the consumption.

More detailed environmental impacts are shown in Fig. 6 . When collecting urine or blackwater separately the net eutrophication impact would reduce to one fifth or even to one eighth. The largest eutrophication impacts were caused by the daily use at the property, including emissions to air and water as well as energy consumption, when applicable. The contribution of the fertilizer use of urine was also significant in the urine separation system due to ammonia losses related to fertilizer spreading. 

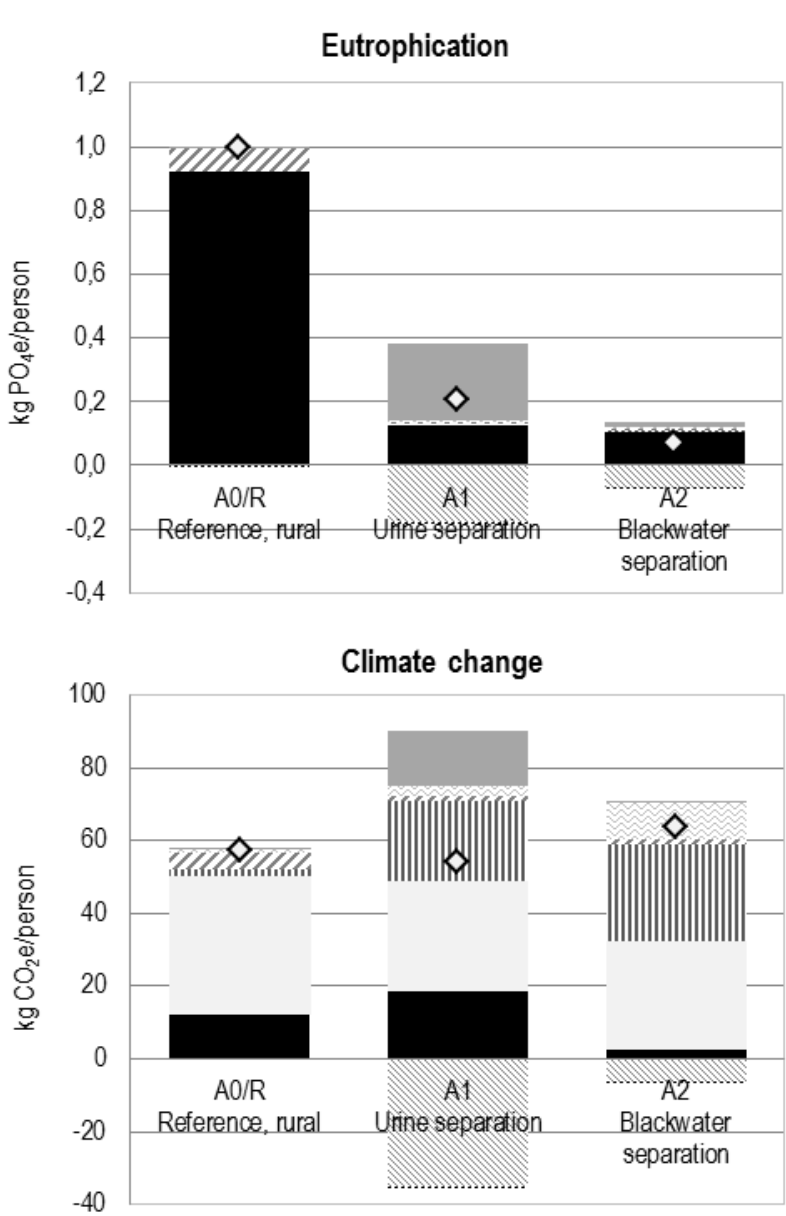

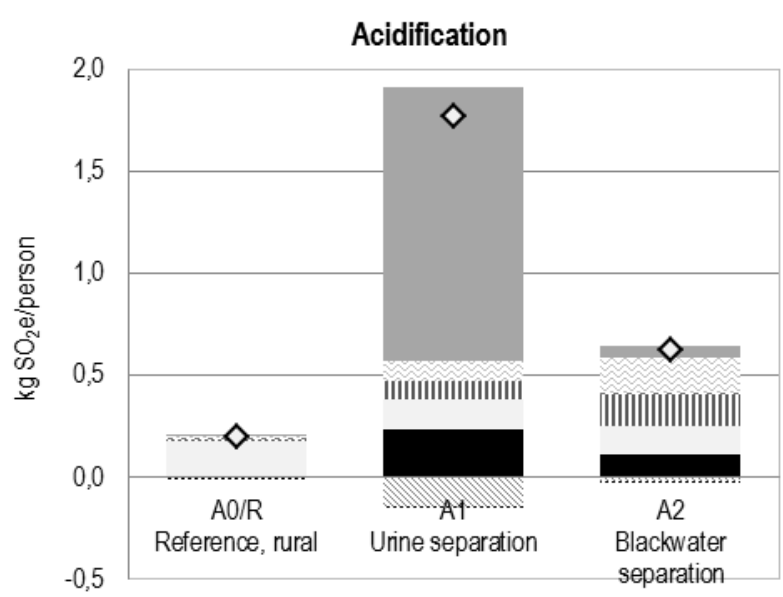

\% Compensations of the energy produced in digestion

* Compensations of the fertilizer use

- Fertilizer use

Further processing of sludge/urine/blackwater

" Treatment of the septic tank sludge at the WWTP

I Toilet system

Sand filter

- Daily use at the property

Fig. 6. Environmental impacts of the alternative systems. White dots indicate the net environmental impacts.

According to the results, the choice of the system had only a very little effect on the net impact of the climate change and the impacts were relatively small in all the alternatives. 58 to $80 \%$ of the total emissions were caused by the on-site sand filter and the toilet system in question. In the urine separation system (A1), home-composting of feces caused rather significant proportion of the emissions of the daily use at the property since the compost was assumed to be mixed with peat. Replacing peat with woodchips, the climate change impacts of composting would decrease, but at the same time ammonia emissions might raise and increase acidification impacts. The compensations of the fertilizer use of urine were also significant in the urine separation system.

The fertilizer use of urine and blackwater increases a risk of acidification, which can be minimized by using advanced spreading techniques where less ammonia is released into the atmosphere. In particular, ammonia losses associated with the application of urine may be even $30 \%$, but with more advanced techniques such as deep injection, the loss can be significantly reduced up to 1 to $10 \%$ (Johansson, 2001; Udert et al., 2006). As a result of lower nitrogen losses connected to the advanced spreading techniques, the amount of soluble nitrogen remains higher in the soil, which in turn might increase the risk of eutrophication.

\subsection{Discussion}

According to the results of this study, the nutrient potential of human urine and feces could be utilized more effectively by applying source separation of urine or blackwater in rural areas, compared to the conventional wastewater treatment system. Four times more phosphorus and over thirty times more nitrogen could be recovered. At the same time, eutrophication impact would be decreased to less than a fifth. More nutrients could be recovered with the blackwater separation system compared to the urine 
separation. Another benefit associated with the first one is that energy will be recovered as biogas. However, to utilize all the nutrient potential of blackwater separation system, also the nutrients of reject water formed as a side stream of blackwater digestion should be recovered. On the other hand, quite an easy processing of urine to fertilizer products, such as struvite, favors the urine separation system. The benefit of the both systems is that blackwater or urine is not mixed with other wastewaters that might contain, aside from pharmaceuticals and hormones, larger amounts of harmful substances and micropollutants.

Overall, the normalized environmental impacts of the blackwater and urine separation systems as well as the reference system were relatively small and contributed only $0.5-0.6 \%$ to climate change, $0.6-5.2 \%$ to acidification and $2.0-15.2 \%$ to eutrophication when compared to the European average annual emissions of the consumption. However, it is difficult to assess the environmental impacts of fertilizer use, because of the changes in weather conditions, soil features, surface shapes, and proximity of watersheds. Also spreading techniques and timing varies. No sensitivity analysis was included in this study. However Lehtoranta et al. (2014) concluded that the sensitivity analysis made to eutrophication impacts, which are also one of the most sensitive in this case, did not have a significant effect on the main conclusions made regarding alternative on-site wastewater treatment systems.

Results indicate that significant environmental benefits could be achieved when applying source separation on a larger scale. For example in the cities and urban areas, the incoming nutrient loads of the WWTPs would drop significantly. It was estimated that if urine of all the Finns was collected and recovered, the nitrogen load to the WWTPs would be reduced to a quarter and the phosphorus load would be halved (Säylä, 2015). As a result, dimensioning of the WWTPs would diminish resulting lower need of energy and chemicals as well as decrease in sludge production. Moreover, eutrophication and emissions of harmful substances to marine and freshwater would decrease.

By exploiting the recovered nutrients as fertilizers, the use of mineral fertilizers would be reduced, as well as the climate impacts of mineral fertilizer production. On the Finnish scale, even up to $10 \%$ of the annual consumption of the mineral fertilizers could be replaced with the nutrients of human urine and excreta, (Ministry of Agriculture and Forestry Finland, 2011a). Compared to manure from cattle and pigs, the annual amount of total nitrogen of the urine of the Finns is at the same level than produced by pigs and half of that produced by cattle. In the case of total phosphorus, the amount is a third and a fifth when compared to pigs and cattle, respectively (Natural Resources Institute Finland, 2016.) Compared with animal manure and mineral fertilizers the heavy metal concentrations of human urine are lower (Jönssön et al., 2004; Winker et al., 2009).

The source separation technologies could be quite easily applied in rural areas. However, in cities and urban areas, the switch to the alternative systems would need more infrastructural changes. In both cases, the challenges are mainly related to technical and logistical issues, like transportation of the collected urine and blackwater to the end user. In the study cases made in Sweden, source separation worked moderately well within the on-site sanitation, blackwater systems performing better than urine systems in general. It was indicated that information exchange between entrepreneurial activity and knowledge development was a major blocking mechanism slowing down the spread of such systems. In addition, organizing the entire system from collection to reuse was found to be challenging (McConville et al., 2017.) Another study showed that one of the main reasons for urine separation systems reverting back to conventional ones were the user's loss of motivation when the recovery of nutrients was not satisfactory (Vinnerås and Jönsson, 2013).

To facilitate the logistical challenges, nutrients of urine and blackwater could be processed to easily transportable products, thus replacing the use of mineral fertilizers. With regard to the profitability of nutrient cycle of human origin as well as other recycling nutrients, a key bottleneck is still the low price of mineral fertilizers and the lack of knowledge about the hazardous substances. The use of new technology should be profitable and there must be a market for the end product to make the technology available. There is also a need for policy instruments and incentives to support the use of recycled fertilizers. For 
example, urine is not allowed to be used as a fertilizer according to the national legislation in Finland. Despite the fact that there are WHO guidelines (WHO, 2006) for the treatment and safe use of urine as a fertilizer, they do not take into account the legislation of different countries and whether urine is permitted for fertilizer use. This is also a factor that prevents or hinders the use of urine as fertilizer, even if its physico-chemical and microbiological quality would be approvable.

There are strong opinions on the use of municipal sludge as well as human urine and feces as fertilizers among public and Finnish food industry. More information is needed about the existence of harmful substances and micropollutants in the end products as well as their behavior in water and soil. According to Viskari et al. (2018), human urine stored according to WHO guidelines (WHO, 2006) fulfilled the criteria of the Finnish legislation (Ministry of Agriculture and Forestry Finland, 2011b), including pathogen indicators and heavy metals. In addition to the requirements of the legislation, the amounts of pharmaceuticals and hormones were analyzed from urine as well as soil and grains after the growing season. All analyzed values were negligible or under the detection limits. It does not, however, exclude possible accumulation in the soil and thus negative effects on soil biota. The conclusion supports also the findings of the Finnish study (Ylivainio et al., 2018), which indicates that direct health risks for human are minor compared to possible risks to soil and soil biota. In any case, too little is known about the short and long-term soil effects of the hazardous substances as well as their impacts on the ecosystem. More research is needed about their behaviour and possible accumulation in the food chain as well as physico-chemical effects on soil. There is also a need to define threshold values for hazardous substances to ensure the safe reuse of the nutrients of human urine and feces and other organic fertilizers. The limit values would set boundaries for future technology development in order to achieve safe end products.

Further studies would be needed also about the feasibility of nutrient recovery and processing in the WWTPs. It could be questioned, is it more feasible to add technology at the end of wastewater treatment process, rather than turn the focus in the beginning of the process or even before the wastewater enters to WWTP. Based on the nutrient potential and fertilizer value calculations as well as the environmental impact assessment, however, environmental benefits and realistic facts support the source separation systems to be used for nutrient recovery. Therefore, the acceptance of the alternative technologies for nutrient recovery and the use of urine and blackwater as fertilizers should be promoted. Moreover, technological means for urine and blackwater collection, logistics and storage should be considered in the future wastewater treatment strategies.

\section{Conclusions and recommendations}

Improved nutrient recovery capability and environmental benefits support the wastewater source separation systems over the conventional ones. Four times more phosphorus and over thirty times more nitrogen could be recovered compared to the conventional systems. At the same time, eutrophication impact is reduced to one fifth. The risk concerning increased soil acidification can be minimized with advanced spreading techniques.

There is a lack of information concerning the risks of hazardous substances of the fertilizer use of human urine and feces. More research and comprehensive risk analysis is needed in order to define proper threshold values for the safe use of recycled end products. Without threshold values, it is impossible to define practices for the safe reuse.

Sustainable and efficient nutrient recycling requires successful management of the whole chain from collection, transportation and storage to processing and end use in order to achieve cost-effective and acceptable end products. There must be a market for the end products otherwise benefits of nutrient recovery will be lost.

In addition to develop technologies, logistics and regulations there is a need for an attitude change to make alternative technologies competitive compared to current ones. 


\section{Acknowledgements}

This study was financially supported by Ministry of the Environment Finland, Programme to promote the recycling of nutrients and to improve the status of the Archipelago Sea, during years 2015-2016. Participation and expertise offered to this project by the Global Dry Toilet Association of Finland is gratefully acknowledged. The authors also gratefully acknowledge Johanna Kallio and Tuomas Mattila (of the Finnish Environment Institute) for providing information and valuable comments during the work.

\section{References}

Aho, M., Pursula, T., Saario, M., Miller, T., Kumpulainen, A., Päällysaho, M., Kontiokari, V., Autio, M., Hillgren, A., Descombes, L., Gaia Consulting, 2015. Ravinteiden kierron taloudellinen arvo ja mahdollisuudet Suomelle. Sitran Studies 99. (In Finnish)

Pantsar, M., Herlevi, K., Järvinen, L., Laita, S., 2016. Leading the cycle - Finnish road map to a circular economy 2016-2025. Sitra Studies 121. (In Finnish)

Andersen, J., Boldrin, A., Christensen, T. \& Scheutz, C., 2010. Greenhouse gas emissions from home composting of organic household waste. Waste Manag. 30, 2475-2482.

https://doi.org/10.1016/j.wasman.2010.07.004

Andersen, J., Boldrin, A., Christensen, T. \& Scheutz, C., 2012. Home composting as an alternative treatment option for organic household waste in Denmark: An environmental assessment using life cycle assessmentmodelling. Waste Manag. 32(1), 31-40. https://doi.org/10.1016/i.wasman.2011.09.014

Brown, S., Subler, S., 2007. Composting and Greenhouse Gas Emissions. Biocycle 48(3), 37-38. https://www.biocycle.net/2007/03/23/composting-and-greenhouse-gas-emissions-a-producersperspective/

Building information Ltd / Rakennustieto Oy, 2013. Haja-asutuksen jätevesien käsittely, RT 66-11133. (in Finnish)

Cordell, D., Rosemarin, A., Schröder, J.J., Smit, A.L. , 2011. Towards global phosphorus security: A systems framework for phosphorus recovery and reuse options. Chemosphere 84(6), 747-758.

https://doi.org/10.1016/i.chemosphere.2011.02.032

Cordell D., Drangert J.O., White S., 2009. The story of phosphorus: Global food security and food for thought. Global Environ. Chang. 19(2), 292-305. https://doi.org/10.1016/j.gloenvcha.2008.10.009

Daelman, M., Van Voorthuizen, E., Van Dongen, U., Volcke, E, Van Loosdrecht, M., 2012. Methane emission during municipal wastewater treatment. Water Res. 46 (11), 3657-3670.

https://doi.org/10.1016/j.watres.2012.04.024

Daelman, M., Van Voorthuizen, E., Van Dongen, U., Volcke, E, Van Loosdrecht, M., 2013. Methane and nitrous oxide emissions from municipal wastewater treatment - results from a long-term study. Water Sci. Technol. 67(10), 2350-2355. https://doi.org/10.2166/wst.2013.109

EUR-Lex, 2015. Closing the loop - An EU action plan for the Circular Economy. Communication from the Commission to the European parliament, the Council, the European economic and social committee and the committee of the regions. 
EUR-Lex, 2008. Commission regulation (EC) no 889/2008 of 5 September 2008 laying down detailed rules for the implementation of Council Regulation (EC) no 834/2007 on organic production and labelling of organic products with regard to organic production, labelling and control.

Eurostat, 2016. Sewage sludge production and disposal.

http://appsso.eurostat.ec.europa.eu/nui/show.do?dataset=env ww spd\&lang=en. (accessed 20 April 2016)

Finnish Consulting Group (FCG), 2008. Current state of water supply and sewerage systems in Finland, MMM 2312-C9259. (in Finnish)

Foley, J., de Haas, Yuan, Z., Lant, P., 2010. Nitrous oxide generation in full-scale biological nutrient removal wastewater treatment plants. Water Res. 44(3), 831-844. https://doi.org/10.1016/j.watres.2009.10.033

Foley, J., Yuan, Z., Keller, J., Senante, E., Chandran, K., Willis, J., Shah, A., van Loosdrect, M., van Voorthuizen, E., 2015. $\mathrm{N}_{2} \mathrm{O}$ and $\mathrm{CH}_{4}$ emission from wastewater collection and treatment systems, $\mathrm{GWRC}$ (Global Water Research Coalition) -report series, volume 14, IWA Publishing.

https://doi.org/10.2166/9781780407340

Genuis, S. J., Birkholz, D., Rodushkin, I., Beesoon, S., 2011. Blood, Urine, and Sweat (BUS) Study: Monitoring and Elimination of Bioaccumulated Toxic Elements. Arch. Environ. Contam. Toxicol. 61(2), 344-357.

https://doi.org/10.1007/s00244-010-9611-5

Grönroos, J., Seppälä, J., Koskela, S., Kilpeläinen, A., Leskinen, P., Holma, A., Tuovinen, J.-P., Turunen, J., Lind, S., Maljanen, M., Martikainen, P., 2013. Life-cycle climate impacts of peat fuel: calculation methods and methodological challenges. Int. J. LCA 18(3), 567-576. https://doi.org/10.1007/s11367-012-0512-x

Heinonen, T., 2014. Biokaasulaitoksen rejektiveden kierrätys prosessivetenä, Hämeen ammattikorkeakoulu, Ympäristötekniikka, Bio- ja elintarviketekniikan koulutusohjelma. (in Finnish)

HSY (Helsinki Region Environmental Services Authority), 2014, 2015, 2016, Wastewater treatment in the metropolitan area Finland. (in Finnish)

IPCC, 2014. Climate Change 2014: Synthesis Report. Contribution of Working Groups I, II and III to the Fifth Assessment Report of the Intergovernmental Panel on Climate Change [Core Writing Team, R.K. Pachauri and L.A. Meyer (eds.)]. IPCC, Geneva, Switzerland, 151 pp.

IPCC, 1996. IPCC Guidelines for National Greenhouse Gas Inventories.

ISO 14040:2006. Environmental Management - Life Cycle Assessment - Principles and Framework.

ISO 14044:2006. Environmental Management - Life Cycle Assessment - Requirements and Guidelines.

Johansson, M., 2001. Urine separation - closing the nutrient cycle. Final report on the R\&D project: source separated human urine - a future source of fertilizer for agriculture in the Stockholm region, Stockholm Water Company.

Jönsson, H., Stinzing, A., Vinnerås, B., Salomon, E., 2004. Guidelines on the use of urine and feces on crop production., Stockholm Environment Institute, Stockholm. https://www.susana.org/en/knowledgehub/resources-and-publications/library/details/187

Kampschreur, M., Temmink, H., Kleerebezem, R., Jetten, M., Van Loosdrecht, M., 2009. Nitrous oxide emission during wastewater treatment. Water Res. 43(17), 4093-4103.

https://doi.org/10.1016/i.watres.2009.03.001 
Kosonen, H., Heinonen, M., Mikola, A., Haimi, H., Mulas, M., Corona, F., Vahala, R., 2016. Nitrous oxide production at a fully covered wastewater treatment plant: Results for a long-term online monitoring campaign. Environ. Sci. Technol. 50(11), 5547-5554. https://doi.org/10.1021/acs.est.5b04466

Kvarnström, E., Emilsson, K., Richert Stintzing, A., Johansson, M., Jönsson, H., Petersens, E., Schönning, C., Christensen, J., Hellström, D., Qvarnström, L., Ridderstolpe, P., Drangert, J.-O., 2006. Urine Diversion: One Step Towards Sustainable Sanitation, Report 2006-1, EcoSanRes Publications Series, Stockholm Environment Institute. http://www.ecosanres.org/pdf files/Urine Diversion 2006-1.pdf

Lapid, D., 2008. Ecological Sanitation: A Hope for a Sustainable Future. http://www.irbnet.de/daten/iconda/CIB DC26761.pdf

Lehtoranta, S., Vilpas, R., Mattila, T., 2014. Comparison of carbon footprints and eutrophication impacts of rural on-site wastewater treatment plants in Finland. J. Clean. Prod. 65(2), 439-446.

https://doi.org/10.1016/j.jclepro.2013.08.024

Lienert, J., Larsen, T.A., 2010. High Acceptance of Urine Source Separation in Seven European Countries: A Review. Environ Sci. Technol. 44(2), 556-566. https://doi.org/10.1021/es9028765

Lienert, J., Bürki, T., Escher, B., 2007. Reducing micropollutants with source control: substance flow analysis of 212 pharmaceuticals in feces and urine. Water Sci. Technol. 56(5), 87-96.

https://doi.org/10.2166/wst.2007.560

Magid, J., Eilersen, A. M., Wrisberg, S., Henze, M., 2006. Possibilities and barriers for recirculation of nutrients and organic matter from urban to rural areas: A technical theoretical framework applied to the medium-sized town Hillerød, Denmark. Ecol. Eng. 28(1), 44-54.

https://doi.org/10.1016/j.ecoleng.2006.03.009

Manninen, K., Grönroos, J., Luostarinen, S., Saastamoinen, M., 2016. Hevosenlannan energiakäytön ympäristövaikutukset., Luonnonvarakeskus, LUKE. (in Finnish)

McConville, J., Kvarnström, E., Jönsson, H., Kärrman, E., Johansson, M., 2017. Source separation: Challenges \& opportunities for transition in the Swedish wastewater sector. Resour. Conserv. Resy. 120(2017), 144156. https://doi.org/10.1016/j.resconrec.2016.12.004

Ministry of the Environment Finland, 2011. Government Decree on Treating Domestic Wastewater in Areas Outside Sewer Networks, 157/2017. (in Finnish)

Ministry of Agriculture and Forestry Finland, 2011a. Suomesta ravinteiden kierrätyksen mallimaa, Helsinki. (in Finnish)

Ministry of Agriculture and Forestry Finland, 2011b. Decree of the Ministry of Agriculture and Forestry on Fertilizer Products, 24/11. (in Finnish)

Myllymaa, T., Moliis, K., Tohka, A., Rantanen, P., Ollikainen, M., Dahlbo, H., 2008. Jätteiden kierrätyksen ja polton käsittelyketjujen ympäristökuormitus ja kustannukset - Inventaarioraportti, Suomen ympäristökeskuksen raportteja 28/2008. (in Finnish) https://helda.helsinki.fi/bitstream/handle/10138/39792/SYKEra 28 2008.pdf?sequence=1\&isAllowed=y

Natural Resources Institute Finland, 2016. Statistics of farm animals in 2015-2016. http://stat.luke.fi/kotielainten-lukumaara (accessed 16 June 2016). 
Osada, T., Kuroda, K., Yonaga, M., 2000. Determination of nitrous oxide, methane, and ammonia emissions from a swine waste composting process. J. Mater. Cycles Waste Manag. 2, 51-56.

https://doi.org/10.1007/s10163-999-0018-1

Pöyry Environment Oy, SITRA, 2007. Lietteenkäsittelyn nykytila Suomessa ja käsittelymenetelmien kilpailukyky -selvitys, Helsinki. (in Finnish)

ReCiPe. ReCiPe methodology for Life Cycle Impact Assessment (LCIA).

Richert Stintzing, A. (ed.), Jönsson, H., Schönning, C., Hinkkanen, K., Kvarnström, E., Ganrot, Z., 2007. Urine Diverting Toilets in Climates with Cold Winters Technical considerations and the reuse of nutrients with a focus on legal and hygienic aspects. WECF (Woman in Europe for a Common Future), Munich, 2007. https://www.susana.org/ resources/documents/default/2-807-urine-diverting-toilets-in-climates-withcold-winters1.pdf

Salmela, M., Kymäläinen, M., 2014. Lietemädättämöselvitys - Suomen lietemädättämöjen kuormitustarkastelu, Häme University of Applied Sciences HAMK, EAKR. (in Finnish)

Schievano, A., D'Imporzano, G., Salati, S. \& Adani, F., 2011. On-field study of anaerobic digestion full-scale plants (Part I): An on-field methodology to determine mass, carbon and nutriens balance. Bioresour. Technol. 102(17), 7737-7744. https://doi.org/10.1016/j.biortech.2011.06.006

Seppälä, J., Knuuttila, S., Silvo, K., 2004. Eutrophication of freshwater ecosystems: a new method for calculating the potential contributions of nitrogen and phosphorus. Int. J. LCA 9(2), 90-100. https://doi.org/10.1007/BF02978568

Spångberg, J., Tidåker, P., Jönsson, H., 2014. Environmental impact of recycling nutrients in human excreta to agriculture compared with enhanced wastewater treatment. Sci. Total Environ. 493, 209-219. https://doi.org/10.1016/j.scitotenv.2014.05.123

Säylä, J., 2015. Urban wastewater treatment 2013. Reports of the Finnish Environment Institute 34/2015. (in Finnish) https://helda.helsinki.fi/bitstream/handle/10138/158957/SYKEra 34 2015.pdf?sequence=1

Swiss Centre for Life Cycle Inventories, 2007. Ecoinvent Database, Version 2.01. http://www.ecoinvent.ch/. (accessed 30 March 2016)

Tampere Water / Tampereen vesi, 2012, 2013, 2014 \& 2015. Vuosikertomus ja vuosikertomuksen tilastotiedot. (in Finnish)

Tukiainen, T., 2009. Vesihuoltolaitosten kasvihuonekaasupäästöt Suomessa, Teknillinen korkeakoulu, Rakennus- ja ympäristötekniikan koulutusohjelma. (in Finnish)

Udert, K.M., Larsen, T.A., Gujer, W., 2006. Fate of major compounds in source-separated urine. Water Sci. Techol. 54(11-12), 413-420. https://doi.org/10.2166/wst.2006.921

VAHTI, 2015. Finnish Compliance monitoring system, Finland's environmental administration. (accessed 5 May 2016)

Vinnerås, B., Jönsson, H., 2013. The Swedish experience with source separation. In: Larsen, T.A., Udert, K.M., Lienert, J. (Eds.), Source Separation and Decentralization for Wastewater Management. IWA Publishing, 415422. https://www.iwapublishing.com/books/9781843393481/source-separation-and-decentralizationwastewater-management 
Vinnerås, B., Jönsson, H., 2002. The performance and potential of faecal separation and urine diversion to recycle plant nutrients in household wastewater. Bioresour Technol. 84(3), 275-282.

https://doi.org/10.1016/S0960-8524(02)00054-8

Viskari E-L., Grobler, G., Karimäki, K., Gorbatova, A., Vilpas, R., Lehtoranta, S. 2018. Nutrient Recovery with Source Separation of Human Urine - Fertiliser Potential and Use in Agriculture. Frontiers in Sustainable Food Systems, section Waste Management in Agroecosystems. https://doi.org/10.3389/fsufs.2018.00032

VTT Technical Research Centre of Finland, 2011. LIPASTO Calculation System. http://lipasto.vtt.fi/. (accessed 3 May 2016)

Wang, J., Zhang, J., Xie, H., Qi, P., Ren, Y., Hu, Z., 2011. Methane emissions from a full-scale A/A/O wastewater treatment plant. Bioresour. Technol. 102(9), 5479-5485.

https://doi.org/10.1016/i.biortech.2010.10.090

Washington State University, 2016. Compost Fundamentals, Biology \& Chemistry, Aerobic Decomposition. http://whatcom.wsu.edu/ag/compost/fundamentals/biology aerobic.htm

Weckman, A., 2005. Nutrients from Toilets to Fields, Guide of the Finnish Garden Association. (in Finnish)

WHO, 2006. Guidelines for the safe use of wastewater, excreta and greywater - Volume 4. Excreta and greywater use in agriculture. World Health Organisation.

http://whqlibdoc.who.int/publications/2006/9241546859 eng.pdf?ua=1

Wicht, H., Beier, M., 1995. N2O Emission aus Nitrifizierenden und Denitrifizierenden Kläranlagen. Korresponendz Abwasser 42(3), 404-406,411-413.

Wiechmann, B., Dienemann, C., Kabbe, C., Brandt, S., Vogel, I., Roskosch, A., 2015. Sewage sludge management in Germany, Umweltbundesamt (UBA), Dessau-Roßlau.

Winker, M., Vinnerås, B., Muskolus, A., Arnold, U., Clemens, J., 2009. Fertilizer products from new sanitation systems: Their potential values and risks. Bioresour. Technol. 100(18), 4090-4096.

https://doi.org/10.1016/j.biortech.2009.03.024

Wäger-Baumann, F., 2011. Physical and biological methods for the treatment of the liquid fraction of anaerobic digester effluent, dissertation, Institut für Umweltbiotechnologie.

https://zidapps.boku.ac.at/abstracts/oe list.php?palD=3\&paSID=8522\&paSF=-1\&paCF=0\&paL-

IST=0\&language $\mathrm{id}=\mathrm{DE}$

Ylivainio, K., Äystö, L., Suominen, K., 2018. Jätevesilietefosforin potentiaali kasvintuotannossa ja vaikutukset ympäristöön ja elintarviketurvallisuuteen, PProduct -projectseminar at Finnish Environment Institute at 4 October 2018. (in Finnish) 